\title{
Komposisi Fitoplankton Pada Tambak Kerang
}

\section{Ken Suwartimah, Ika Desie Wulandari, Retno Hartati* dan Sri Redjeki}

\author{
Departemen IImu Kelautan, Fakultas Perikanan dan IImu Kelautan, Universitas Diponegoro \\ JI. Prof. Soedarto, SH. Kampus UNDIP Tembalang, Semarang 50275 \\ Email : retnohartati.undip@yahoo.com
}

\begin{abstract}
This study aims to determine to determine the species composition, abundance and community structure of phytoplankton in shellfish aquaculture ponds blood (Anadara granosa) in Menco, District Wedung, District Demak.Metode used in this study is Diskriptif method, determination of the location of the study is purposive sampling Methods, namely the determination of the sampling locations should be based on consideration, the station I to III of the sampling stations representing keselurvan research area. Marine research station is Blood Shellfish Farming in Hamlet Menco. Station is divided into three stations, with making four periods. Environmental parameters taken include: salinity, temperature, $\mathrm{pH}, \mathrm{DO}$, nitrate, phosphate, dissolved oxygen, organic materials. The results of the study, found 19 genera of phytoplankton. Phytoplankton abundance 2596-18844 cells / L. Diversity index (H ') based on the total period ranged from 1.098 to 1.837. On January 18-March 3, 2014, categorized into the diversity index medium. Uniformity index (e) the entire period ranged from 0.616 to 0.999 .
\end{abstract}

Keywords: composition, phytoplankton, cockle pond

\begin{abstract}
Abstrak
Fitoplankton atau mikroalga merupakan makanan utama kerang di tambak. Penelitian ini bertujuan untuk mengetahui komposisi jenis, kelimpahan, dan struktur komunitas fitoplankton pada tambak budidaya kerang darah (Anadara granosa) di Menco, Kecamatan Wedung, Kabupaten Demak. M etode yang digunakan dalam penelitian ini adalah metode Deskriptif. Sampel fitoplankton diambil dari Tambak Kerang Darah selama empat periode. Parameter lingkungan sebagai data penunjang adalah salinitas, suhu, $\mathrm{pH}$, DO, nitrat, fosfat, oksigen terlarut, bahan organik. Hasil penelitian menjunjukkan terdapat 19 genus fitoplankton, dengan kelimpahan 2.5-18.8 $10^{3} \mathrm{sel} . \mathrm{L}^{-1}$. Indeks keanekaragaman ( $\left.\mathrm{H}^{\prime}\right)$ berdasarkan total keseluruhan periode berkisar antara 1,098-1,837. Pada tanggal 18 Januari3 Maret 2014, dikategorikan masuk dalam indeks keanekaragaman sedang. Indeks keseragaman (e) keseluruhan periode berkisar antara 0,616-0,999.
\end{abstract}

Kata Kunci : Fitoplankton; Tambak Kerang Darah

\section{PENDAHULUAN}

Kerang darah (Anadara granosa) adalah sejenis kerang dari famili Arcidae yang biasa dimakan oleh masyarakat di Asia pada umumnya. Budidaya kerang darah sudah dilakukan dan memiliki nilai ekonomi yang baik. Lokasi budidaya dapat dilakukan di laut (bagian pinggir) maupun di dalam tambak. Salah satu lokasi budidaya kerang adalah Desa Menco, di kecamatan Wedung Kabupaten Demak. Daerah tersebut merupakan kawasan pemukiman yang padat penduduk. Perairan di Desa Menco mendapat pengaruh dari daratan melalui sungai yang mengalirkan air tawar. Tambak budidaya Kerang Darah mendapat pengaruh perairan di sekitarnya. Faktor-faktor lingkungan perairan seperti nutrien dan fisika-kimia perairan selalu di butuhkan organisme yang ada di dalamnya untuk dapat berkembang maupun bertahan hidup. Kerang darah merupakan hewan yang bersifat filter feeder yang memakan 
fitoplankton. Fitoplankton merupakan organisme yang mempunyai pengaruh besar terhadap kehidupan di suatu perairan baik langsung maupun tidak langsung dan dijadikan sebagai salah satu parameter dalam pemantavan kualitas perairan.

Fitoplankton didefinisikan sebagai organisme tumbuhan mikroskopik yang hidup melayang, mengapung di dalam air dan memiliki kemampuan gerak yang terbatas. Fitoplankton juga memegang peranan yang sangat penting dalam suatu perairan. Fungsi ekologinya sebagai produsen primer dan awal mata rantai dalam jaring makanan menyebabkan fitoplankton sering dijadikan skala ukuran kesuburan suatu perairan. Fitoplankton selain berfungsi dalam keseimbangan ekosistem perairan budidaya, juga berfungsi sebagai pakan alami di dalam usaha budidaya. Fitoplankton juga merupakan produsen atau sumber daya pakan bagi ikan (Marsambuana, 2008). secara berkesinambungan. Salah satu kegiatan pemantavan ini adalah dengan melakukan penelitian mengetahui komposisi jenis, kelimpahan, dan struktur komunitas fitoplanktondi tambak budidaya kerang darah (Anadara granosa) di Dusun Menco, Kecamatan Wedung, Kabupaten Demak.

\section{MATERI DAN METODE}

Materi yang digunakan dalam penelitian ini adalah fitoplankton yang diambil dari tambak yang dibudidayakan oleh petani tambak di Dusun Menco, Kecamatan Wedung, Kabupaten Demak.

Metode penelitian yang digunakan dalam penelitian ini adalah Metode Diskriptif yaitu pengumpulan data yang bertujuan untuk menjelaskan suatu gambaran keadaan tanpa mengambil keputusan secara umum sistematis, aktual, dan akurat (Arikunto, 2002). Metode pengambilan sampel dilakukan dengan menggunakan Purposive Sampling Method, (Hadi, 1980). Pengambilan sampel di lapangan sebanyak empat kali pengambilan. Teknis penelitian dibagi menjadi 4 bagian yaitu penentuan lokasi, pengamvbilan sample fitoplankton, identifikasi fitoplankton, analisa data.

Penelitian ini dilakukan pada tanggal 18 januari 2014 - 3 Maret 2014 yang di bagi menjadi empat periode. Setiap pengambilan sampel dilakukan dua minggu sekali. Setiap kali sampling dilakukan 3 kali pengulangan. Pada lokasi tersebut diambil sampel air dengan menggunakan planktonnet.

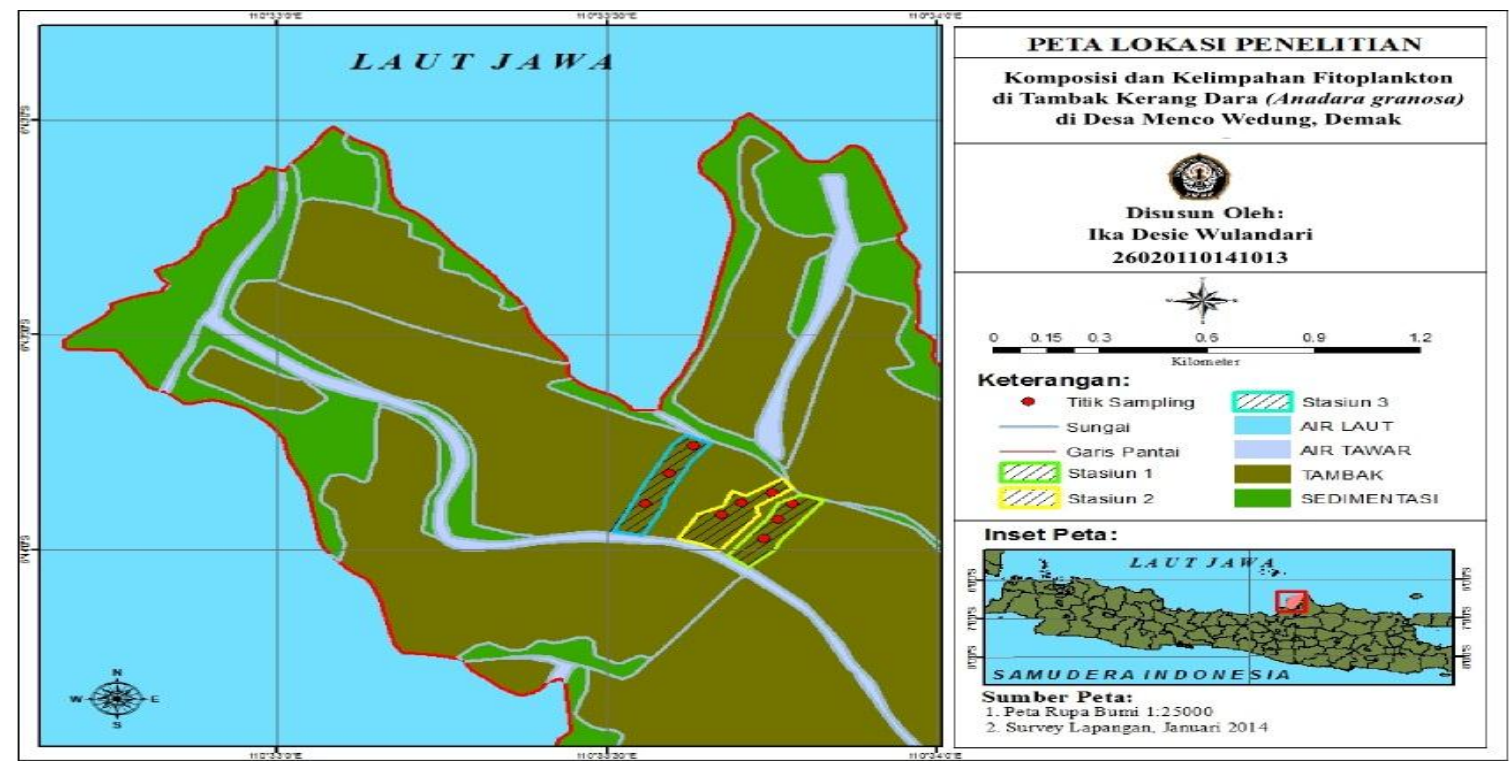

Gambar 1. Peta Lokasi penelitian fitoplankton di tambak kerang darah di Dusun Menco, Wedung, Demak. 
Sampel air yang diperoleh dimasukkan kedalam botol plastik sebanyak $500 \mathrm{ml}$ dan diawetkan dengan menambahkan larutan alkohol $4 \%$. Selanjutnya sampel yang telah diperoleh dibawa ke laboratorium untuk diidentifikasikan menggunukan mikroskop dan buku identifikasi (Yamaji, 1979).

Analisis data kelimpahan fitoplankton dihitung berdasarkan persamaan menurut APHA (1989):

$N=O i / O p \times V r / V o \times 1 / V s \times n / p$

Keterangan :

$\mathrm{N}=$ Jumlah individu per liter

Oi $=$ Luas gelas penutup preparat $\left(\mathrm{mm}^{2}\right)$

$O p=$ Luas satu lapangan pandang $\left(\mathrm{mm}^{2}\right)$

$\mathrm{Vr}=$ Volume air tersaring $(\mathrm{ml})$

$V_{0}=$ Volume air yang diamati (ml)

$V_{s}=$ Volume air yang disaring $(\mathrm{L})$

$\mathrm{n}=$ Jumlah plankton pada seluruh lapangan pandang.

$\mathrm{P}=$ Jumlah lapangan pandang yang teramati

untuk menghitung insdeks

keanekaragaman menggunakan rumus (Krebs, 1985) :

$$
\mathrm{H}^{\prime}=-\sum_{\mathrm{n}=1}^{\mathrm{s}} P i \ln P i
$$

Keterangan :

$\mathrm{H}^{\prime} \quad=$ Indeks keanekaragaman jenis

$\mathrm{s}=$ Jumlah spesies

$\mathrm{Pi}=$ Kelimpahan relatif (ni/N)

$\mathrm{ni}=$ jumlah individu spesies ke-i

$\mathrm{N}=$ Jumlah total individu

Menurut Prawiradilaga (2003) yang mengacu pada index Shannon-Wiener, $\mathrm{H}^{\prime}$ $<1$ : Keanekaragam komunitas rendah (tidakstabil), $H^{\prime}=1-3$ : Keanekaragaman sedang (kestabilannyasedang), $\mathrm{H}^{\prime}>3$ : Keanekaragaman komunitas tinggi (stabil)

Indeks Keseragaman menggunakan rumus (Krebs, 1972)

$$
E=H^{\prime} / H_{\max }
$$

$\mathrm{H}^{\prime}=$ Indeks keanekaragaman ShannonWiener

$\mathrm{E}=$ Indekskeseragaman

$\mathrm{H}_{\text {max }}=$ Indekskeanekaragaman maksimum

Menurut Odum (1971), Indeks dominansi adalah perbandingan kuadrat antara kelimpahan individu suatu jelis dengan jumlah keseluruhan individu dalam komunitas. Dirumuskan sebafgai berikut:

$$
\mathrm{C}=\sum\left[\frac{\mathrm{ni}}{\mathrm{N}}\right]^{2}
$$

Keterangan :

C : Indeks dominansi

$\mathrm{n}$ : Jumlah individu jenis ke $-\mathrm{i}$

$\mathrm{N}$ : Jumlah seluruh individu Kriteria indeks dominansi

\section{HASIL DAN PEMBAHASAN}

\section{Komposisi Fitoplankton}

Berdasarkan dari hasil pengamatan fitoplankton yang telah dilakukan pada tambak kerang darah di Dusun Menco, Kecamatan Wedung, Kabupaten Demak, dalam periode sampling dari bulan Januari-Maret 2014 dengan empat kali pengambilan sampel pada 3 stasiun, ditemukan 19 genus fitoplankton yang termasuk dalam 2 kelas yaitu Bacillariophyceae (16 genus) dan Dhinophyceae (3 genus). Hasil penelitian juga menunjukkan bahwa genus yang selalu terdapat pada setiap periode selama penelitian adalah genus Nitzchia, Navicula, Gyrosigma, dan Rhizosolenia dari kelas Bacillariophyceae. Hal ini terjadi karena berkaitan dengan kemampuan dari genus tersebut, yang dapat beradaptasi dengan lingkungan sehingga mampu bertahan di tambak. Menurut Romimohtarto dan Juwana (2001), beberapa genus Bacillariophyceae mempunyai kemampuan terhadap perubahan kualitas lingkungan sekitarnya. Selain itu, distribusi Bacillariophyceae sangat luas meliputi perairan air laut sampai air tawar, baik dalam komunitas plankton maupun bentik (Sze, 1993). Komposisi jenis fitoplankton kelas Dinophyceae yang ditemukan selama 


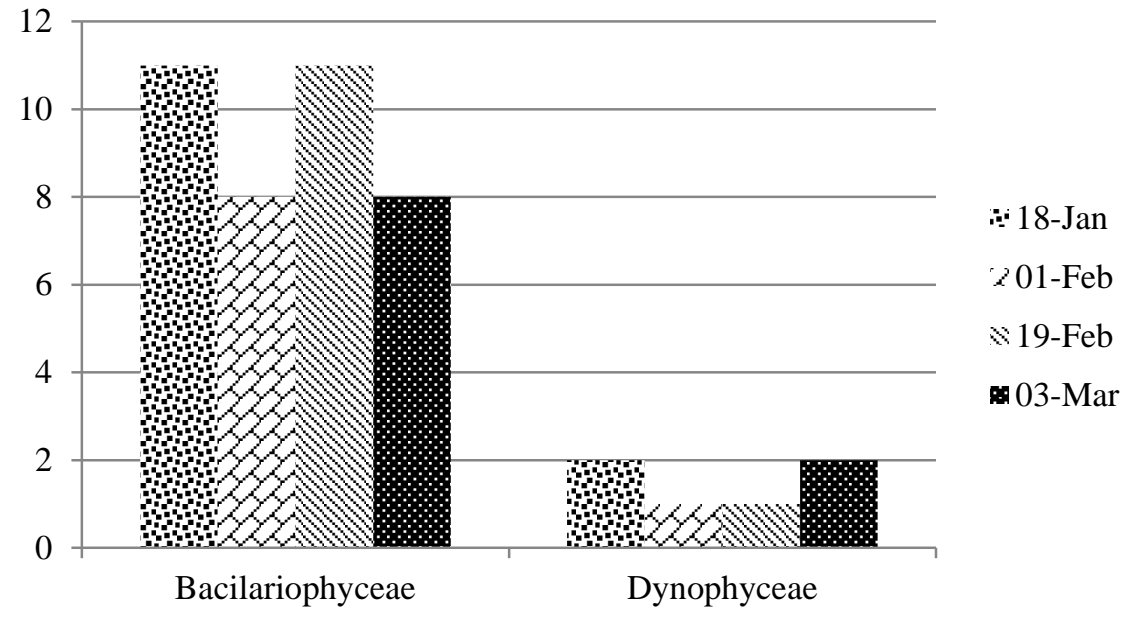

Gambar 2. Jumlah genus fitoplankton yang ditemukan pada tambak Kerang Darah

penelitian berjumlah tiga genus, yaitu Ceratium, Diploneis, dan Triceratium. Jenisjenis fitoplankton tersebut paling sedikit ditemukan pada saat penelitian diduga karena ketidakmampuan beberapa jenisjenis tersebut untuk beradaptasi terhadap lingkungan parairan tambak tersebut.

Hasil penelitian menunjukan bahwa dari dua kelas yang ditemukan selama bulan Januari-Maret 2014 di tambak Dusun Menco, kelas Bacillariophyceae memiliki jumlah genus yang lebih banyak dibandingkan dengan Dynophyceae. Keadaan ini di perkirakan karena kelas Bacillariophyceae (diatom) memiliki sebaran yang cukup luas. Hal ini dinyatakan oleh Arinardi (1997) bahwa kelas Bacillariophyceae (diatom) merupakan anggota fitoplankton yang terbanyak (dominan) di perairan pada tambak. Sahlan (1990) menyatakan fitoplankton di tambak berasal dari genera Navicula, Cocconeus, Gyrosygisma, dan Pleurosygma. Dari 2 kelas total jumlah yang ditemukan 19 genus. Pada penelitiannya di perairan terabrasi yang digunakan untuk budidaya Kerang Darah, Atmaja et al. (2014) menemukan 23 species fitoplankton, yang lebih banyak daripada diperairan tambak di Dusun Menco.

\section{Kelimpahan Fitoplankton}

Kelimpahan total fitoplankton selama bulan Januari-Maret 2014 (Tabel 3)

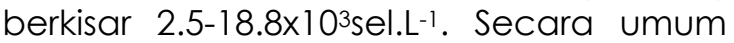

kelimpahan total fitoplankton pada saat kondisi hujan pada tanggal 18 Januari dan 19 Februari 2014 kelimpahan lebih tinggi daripada pada tanggal 3 Maret 2014. Kelimpahan fitoplankton pada saat tanggal 18 Januari - 1 Februari 2014 berkisar antara 13.73-18.84x1035el.L-1, sedangkan kisaran kelimpahan fitoplankton pada tanggal 19 Februari dan 3 Maret 2014 antara 2.6-9.2 $\times 10^{3} \mathrm{sel}^{\mathrm{S}} \mathrm{L}^{-1}$. Ketersediaan makanan (fitoplankton) akan berpengaruh terhadap kelulushidupan dan pertumbuhan kerang darah (Atmaja et al., 2014).

Selama penelitian, genus pada kelas Bacillariophyceae lebih sering ditemukan daripada Dinophyceae. Kondisi tersebut disebabkan oleh adanya daya adaptasi kelas tersebut yang lebih baik dari kelas kelas lainnya di tambak penelitian. Waktu penelitian adalah pada musim hujan, yaitu bulan Januari 2014 - Februari 2014, sehingga memiliki intensitas penyinaran yang kurang karena banyak awan yang menghalangi penyinaran yang sampai di perairan. Kelas Bacillariophyceae merupakan fitoplankton tipe teduh, yaitu mampu hidup di dasar atau di bawah lapisan permukaan yang masih ada sinar walaupun sedikit (Baksir, 2004). Menurut Cornellius (1999) kelas diatom akan hidup dengan baik pada suhu $28-30^{\circ} \mathrm{C}$, sedangkan suhu perairan selama penelitian menunjukkan nilai $25-33.2^{\circ} \mathrm{C}$. Hasil kelimpahan plankton yang di identifikasi Atmaja et al., (2014) kebanyakan merupakan fitoplankton dari 
jenis diatom yang merupakan sumber pakan alami untuk pertumbuhan dan kelangsungan hidup kerang darah. Diatom yang melimpah dapat dimanfaatkan untuk kegiatan budidaya yang dimanfaatkan sebagai makanan alami untuk biota yang dibudidaya. Menurut Edhi et. al. (2003) salah satu fitoplankton yang digunakan untuk kegiatan budidaya sebagai pakan alami salah satunya adalah Nitzschia palea yang termasuk dalam diatom.

Indeks Keanekaragaman, Keseragaman, dan Dominansi

Indeks keanekaragaman $\left(\mathrm{H}^{\prime}\right)$ fitoplankton pada tambak Kerang Darah selama penelitan berkisar 1.098-1.837 (Gambar 4), termasuk pada kategori sedang. Secara umum tingkat keanekaragaman di perairan tambak Dusun Menco, Kecamatan Wedung, Kabupaten Demak, dipengaruhi oleh kondisi fisika dan kimia perairan. Menurut Supriharyono (2000), keanekaragaman fitoplankton dipengaruhi oleh percampuran air tawar dan air laut. Indeks keseragaman (e) fitoplankton selama penelitian termasuk dalam kategori tinggi dengan nilai berkisar 0.616-0.999 (Gambar 4). Indeks Dominansi (c) menurut pertimbangan berdasarkan periode berkisar antara 0.001-0.384 dan termasuk dalam kategori rendah, artinya tidak ada dominasi salah satu genus fitoplankton di tambak kerang darah.

Hal ini menunjukkan bahwa indeks keseragaman (e) fitoplankton di tambak Dusun Menco selama penelitian termasuk dalam kriteria tinggi. Indeks keseragaman menunjukkan penyebaran suatu jenis fitoplankton di suatu populasi, semakin nilai indeks (mendekati 1) maka semakin besar pula keseragaman populasi yang berarti bahwa penyebaran jumlah dari individu adalah sama dan tidak ada
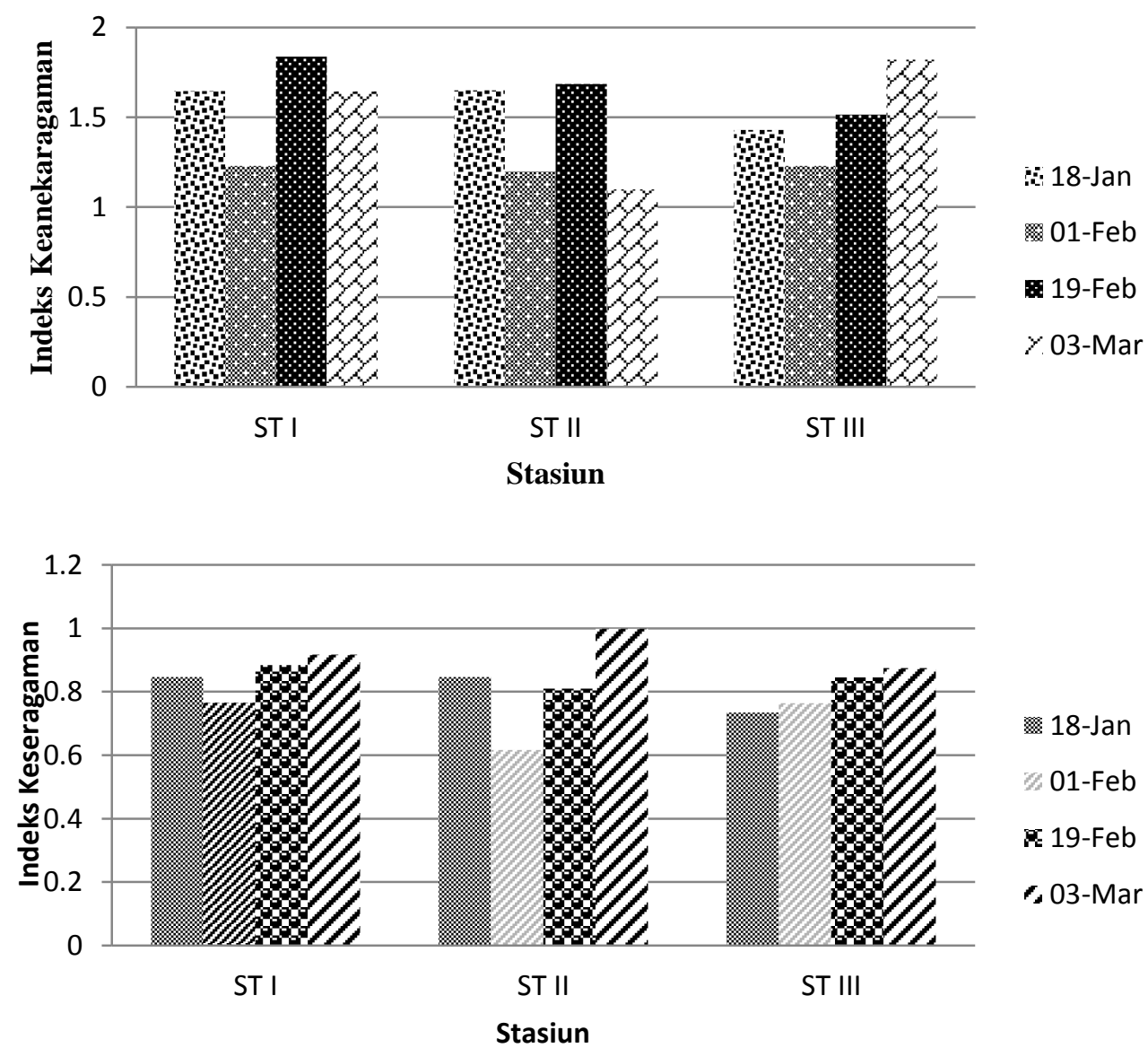

Gambar 4. Indeks keanekaragaman dan keseragaman fitoplankton pada tambak Kerang Darah 
kecenderungan terjadinya dominansi oleh suatu jenis (Dianthani, 2003).

Berdasarkan pengukuran yang dilakukan selama penelitian di tambak kerang darah, suhu berkisar $25.8-32.8^{\circ} \mathrm{C}$; salinitas berkisar 10-22\%, dan $\mathrm{pH}$ berkisar 6.23-8.52. Kandungan oksigen terlarut di tambak kerang darah berkisaran 78,63ppm, kadar nitrat dan fosfat berturutturut berkisar 1.1-1.4 dan 0.28-0.56mg.L-1, sedangkan bahan organik sedimen berkisar 2.78-3.17\%.

Kelimpahan tertinggi di lokasi
penelitian juga disebabkan oleh ketersediaan unsur hara yang memadai bagi perkembangan fitoplankton. Anggoro (1984) menyatakan kandungan nitrat 0,1 - 4,5 ppm di perairan sangat optimum bagi produktifitas fitoplankton. Hal tersebut sesuai dengan nilai yang diperoleh saat penelitian $10,9 \mathrm{mg} / \mathrm{L}-2,0$ $\mathrm{mg} / \mathrm{L})$. Selain kandungan nitrat, kandungan Fosfat juga sangat melimpah di perairan tambak tersebut $(0,76 \mathrm{mg} / \mathrm{L})$. Untuk pertumbuhan optimal, fitoplankton memerlukan kandungan fosfat pada kisaran $0,09 \mathrm{mg} / \mathrm{L}-1,80 \mathrm{mg} / \mathrm{L}$, dan jumlah fosfat yang melimpah akan mengalami ledakan populasi fitoplankton pada suatu perairan (Mackethum, 1969). Kandungan nutrien, untuk dua kelas yang ditemukan sudah mencukupi sebagai kebutuhan pertumbuhan fitoplankton. Demikian juga dengan beberapa parameter lingkungan yang ada, sudah sangat sesuai untuk kondisi ekologi dan optimum bagi pertumbuhan fitoplankton. Kelompok Bacillariophyceae (diatom) mampu melakukan pembelahan satu kali dalam 24 jam pada kondisi zat hara yang stabil. Dengan demikian, diatom selalu akan memanfaatkan pasokan zat hara dari darat (aliran sungai) lebih cepat dan efektif daripada kelompok fitoplankton lainnya. Dapat diasumsikan kelompok Bacillariophyceae (diatom) selalu mendominasikan kelompok fitoplankton di muara sungai dan perairan tambak

\section{KESIMPULAN}

Berdasarkan pengamatan, ditemukan 19 genus fitoplankton di perairan tambak di Dusun Menco, Kecamatan Wedung, Kabupaten Demak. Genus dari Bacillariaceae (diatom) memiliki 16 genus yaitu Amphora, Ceratiulina, Cocconies, Coscinodiscus, Fragilaria, Gyrogsigma, Navicula, Nitzchia, Pleurosigma, Rhizosolenia, Surirella, Thassionema, Thalassiosira, Skelotonema, Thassiothrix, Pelagothrix. Genus Gyrosigma, Navicula, Nitzchia, Pleurosigma, selalu ditemukan hadir pada setiap stasiun di periode keseluruhan pada tambak penelitian. Sedangkan pada kelas Dinophyceae hanya ditemukan tiga genus yaitu Ceratium, Diploneis, dan Triceratium yang di temukan pada beberapa stasiun penelitian dari keseluruhan periode. Kelimpahan fitoplankton memiliki kisaran antara sebesar 18.844 sel/L, sedangkan kelimpahan terendah ditemukan pada tanggal 1 Maret 2014 di stasiun II sebesar $2.596 \mathrm{sel} / \mathrm{L}$. Kelimpahan total fitoplankton tertinggi terdapat pada stasiun Ilpada periode tanggal 18 Januari 2014 dan kelimpahan total fitoplankton terendah terdapat pada stasiun II pada tanggal 1 Maret 2014

Indeks keanekaragaman ( $\left.\mathrm{H}^{\prime}\right)$ berdasarkan total keseluruhan periode berkisar antara 1,098-1,837. Pada tangaal 18 Januari - 1 Maret 2014 dikategorikan masuk dalam indeks keanekaragaman sedang. Indeks keseragaman (e) keseluruhan periode berkisar antara 0,616 $-0,999$ sehingga termasuk dalam kategori tinggi.

\section{DAFTAR PUSTAKA}

Atmaja, B.S., Rejeki, S., dan Wisnu, R. 2014. Pengaruh padat tebar terhadap pertumbuhan dan kelulushidupan kerang darah (Anadara granosa) yang dibudidaya di perairan terabrasi Desa Kaliwlingi Kabupaten Brebes. J. Aquacul. Management Technol. 3(4): 207-213

Arinardi, O. H., Sutomo A. B., Yusuf S. A., Trimaningsih., Asnaryanti dan Riyono S. H. 1997. Kisaran kelimpahan dan komposisi plankton predominan di kawasan Timur Indonesia. P3O LIPI, Jakarta. $140 \mathrm{hlm}$. 
Baksir, A., 2004. Hubungan antara produktivitas primer fitoplankton dan intensitas cahaya di Waduk Cirata Kabupater Cianjur Jawa Barat. Makalah Falsafah Sains Program Pasca Sarjana (S3) Institut Pertanian Bogor (IPB)

Cornellius, E., 1999. Kajian diatom di Perairan Pulau Pangkor.

Dianthani, D., 2003. Identifikasi jenis plankton di Muara Badak, Kalimantan Timur. Makalah Falsafah Sains Program Pasca Sarjana (S3) Institut Pertanian Bogor.

Edhi, W., Pribadi. A., dan Kurniawan, J. 2003. Plankton di Lingkungan PT. Central Pertiwi Bahari : Suatu Pendekatan Biologi dan Manajemen Plankton dalam Budidaya Udang. PT. Central Pertiwi Bahari, Lampung.

Krebs, C.J. 1985. Ecology. The Experimental Analysis of Distribution Abundance. Third Edition. Harper and Row Publisher. New York, 776 pp.

Marsambuana, P.A. 2008. Hubungan Keragaman Fitoplankton dengan Kualitas Air di Pulau Bauluang, Kabupaten Takalar, Sulawesi Selatan. Balai Riset Perikanan Budidaya Air Payau, Maros. J. Biodiv. 9(3): 22 - 217.

Nybakken,J.,W.1992. Biologi Laut; Suatu Pendekatan Ekologis. Jakarta : PT. Gramedia Pustaka Utama.
Prawiradilaga, D. M., A Suyanto, W. A. Noerdjito, A. Salim, Purwaningsih, I. Rachmatika., S. Susiarti, I. Dan Shidiq, A. Marakarmah, M. H. Sinaga, E. Chalik, Ismael, M. Maharani, Y. Purwanto dan E. B. Waluyo. 2003. Final Reporto and Biodiversity of Tesso Nilo. Rersearch Center for Biologi - LIPI and WWF Indonesia, Jakarta, $4 \mathrm{hlm}$.

Riswanto, 2005. Struktur Komunitas Fitoplankton di Wilayah Plawangan, Klaces dan Donan Laguna sagara Anakan Cilacap. Skripsi. Jurusan IImu kelautan Fakultas Perikanan dan IImu Kelautan Universitas Diponegoro. (Tidak dipublikasikan). $93 \mathrm{hlm}$.

Romimohtarto, K. dan S, Juwana. 1999. Biologi Laut. Puslitbang Oseanologi LIPI:Jakarta.

Supriharyono, 2000. Pelestarian dan Pengelolaan Sumber Daya Alam di Wilayah Pesisir Tropis. PT. Gramedia Pustaka Utama. Jakarta. HIm 31 - 44.

Odum, E. P. 1971. Fundamental of Ecology. Third Edition, W.B. Sunders Company. Toronto. $574 \mathrm{p}$.

Yamaji, I. 1996. Illustration of Marine Plankton of Japan. Hoikusha Publishing Co. Ltd. Japan. 